\title{
Natural products to control biofilm on painted surfaces
}

\author{
Sofia Bogdan \\ Centro de Investigación y Desarrollo en Tecnología de Pinturas, La Plata, Argentina \\ Cecilia Deya \\ Centro de Investigacion y Desarrollo en Tecnologia de Pinturas, La Plata, Argentina and Faculty of Engineering, \\ Universidad Nacional de la Plata, La Plata, Argentina \\ Oscar Micheloni \\ Department of Basic Sciences, Universidad Nacional del Noroeste de la Provincia de Buenos Aires, Junin, Argentina \\ Natalia Bellotti \\ Centro de Investigacion y Desarrollo en Tecnologia de Pinturas, La Plata, Argentina and Faculty of Natural Sciences and Museum, \\ Universidad Nacional de La Plata, La Plata, Argentina, and \\ Roberto Romagnoli \\ Centro de Investigacion y Desarrollo en Tecnologia de Pinturas, La Plata, Argentina and Faculty of Exact Sciences, \\ Universidad Nacional de la Plata, La Plata, Argentina
}

\begin{abstract}
Purpose - This paper aims to study five vegetables extracts as possible additives to control bacterial growth on indoor waterborne paints. The extracts were obtained from the weeds Raphanus sativus, Rapistrum rugosum, Sinapis arvensis, Nicotiana longiflora and Dipsacus fullonum, used in traditional medicine as antimicrobial compounds.

Design/methodology/approach - Weeds extracts were characterized by Fourier transform infrared spectroscopy and UV-Vis spectrophotometry. Their antibacterial activity against Escherichia coli and Staphylococcus aureus was also determined. Afterward, selected extracts were incorporated in waterborne paint formulations. The paints' antimicrobial activity was assessed against $S$. aureus, monitoring biofilm formation by environmental scanning electron microscopy.

Findings - As a general rule, results showed that tested paints were efficient in inhibiting biofilm formation, especially that formulated with Nicotiana longiflora.

Practical implications - The tested paints can be used to protect walls from microbial colonization, which shortened coatings' useful life by discoloration and/or degradation. Concomitantly, indoor microbial colonization by aerosols could be also diminished. This is especially important in places that should have high standards of environmental hygiene, as in the food industry, health-care and sanitary centers.

Originality/value - The main value of this research was to study the antimicrobial activity of weeds extracts and to incorporate them in waterborne paints to diminish bacterial biofilm formation. This biofilm discolors and degrades the paint, and causes health problems. The use of natural compounds in coatings is increasing because of the convenience of using renewable sources, such as natural antimicrobials, in paint formulations.
\end{abstract}

Keywords Bacteria, FTIR spectroscopy, Microorganisms, Biocides, Coating biodeterioration, Vegetables extracts, Antimicrobial paints, Biofilm, Inhibition

Paper type Research paper

The ability of microorganisms to colonize diverse surfaces, grow and develop into a biofilm constitute a serious problem for numerous industries including medical, food and marine (Videla and Herrera, 2005; Yebra et al., 2006; Guerrero et al., 2009; Héquet et al., 2011). A biofilm can be defined as an accumulation of microorganisms and their extracellular matrix to form a structured community onto a given surface (Tenke

The current issue and full text archive of this journal is available on Emerald Insight at: www.emeraldinsight.com/0369-9420.htm

Pigment \& Resin Technology

$47 / 2(2018) 180-187$

(C) Emerald Publishing Limited [ISSN 0369-9420]

[DOI 10.1108/PRT-01-2017-0004] et al., 2004). These matrices protect microorganisms from being removed and facilitate their survival under unfavorable conditions or sudden climate changes (Otto, 2013). Moreover, it has been demonstrated that the biofilm shields bacteria from the action of antibacterial agents (Costerton et al., 1995;

The authors are grateful to Consejo Nacional de Investigaciones Científicas y Técnicas, Universidad Nacional de La Plata and Comisión de Investigaciones Científicas de la Provincia de Buenos Aires for their sponsorship to do this research. The authors also wish to thank Dr Teresa Del Panno for her technical assistance.

Received 4 January 2017

Revised 5 April 2017

16 June 2017

Accepted 26 July 2017 
Gilbert et al., 2002). Several factors influence surfaces colonization by microorganisms, principally a high relative ambient humidity and/or temperature. The availability of organic compound such as cellulose, frequently present in a typical indoor paint as thickener, contributes to feed microorganisms (Garg et al., 1995).

In recent years, substantial scientific evidence proved that environmental contamination of surfaces in hospital rooms plays an important role in the transmission of several key health care-associated pathogens (Staphylococcus aureus, Enterococcus species, Clostridium difficile, Acinetobacter species and norovirus; Costerton et al., 1999; Weber et al., 2013).

Cleaning or disinfecting the environment can reduce infection transmission (Kramer et al., 2006). This fact has driven the control of microorganisms in the environment using new materials with inherent antimicrobial properties (Sambhy et al., 2006; Schneider, 2013; Hoque et al., 2015). In this sense, antimicrobial paints are very useful because they are designed to avoid bacterial and fungal colonization of the painted surface (Hare, 2000; Johns, 2003), thus contributing to the hygiene of buildings (Sontakke et al., 2012) and extending the useful life of the coating. Taking into account that it is necessary to look for renewable and environmentally friendly antimicrobial agents, the development of ceiling and wall paints formulated with vegetables extracts with antimicrobial activity, instead of synthetic biocides, results promissory.

Vegetables extracts are a complex mixture of different compounds, generally related to each other, which may have antimicrobial activity on different targets (Inoue et al., 2004; Laks, 1987; Scalbert, 1991). Among these compounds, polyphenols, flavonoids, terpenoids, alkaloids, etc. can be mentioned. Vegetables extracts as well as essential oils, both are gaining more acceptance among researchers because of their natural origin, abundance and safety of use (Binorkar and Jani, 2012; Bonjar, 2004).

The objective of this research was to evaluate five vegetables extracts to determine their ability to inhibit bacterial growth. The most active extracts were used to develop, later, an antimicrobial paint to prevent the microbial colonization of surfaces. Microbial colonization of surfaces is preceded by the biofilm formation. The extracts used were obtained from the weeds Raphanus sativus, Rapistrum rugosum, Sinapis arvensis, Nicotiana longiflora and Dipsacus fullonum, common in Argentina.

In a first step, the antimicrobial activity of the extracts was evaluated against two strains Escherichia coli (ATCC 11229) and Staphylococcus aureus (ATCC, 6538). These bacteria are important because they are closely related to human health. For example, $S$. aureus strains, especially those resistant to the drug methicillin referred as methicillin-resistant (MRSA), play an important role in infections acquired by hospitalized patients. In a second step, water-based antimicrobial paints were formulated using the extracts, which exhibited antimicrobial activity. Finally, the resistance of waterborne paint against bacterial biofilm development was assessed. It was found that acrylic-styrene waterborne paints, containing Nicotiana longiflora inhibited biofilm formation.

\section{Materials and methods}

\subsection{Selection of the vegetables}

The weeds Raphanus satious ( $\mathrm{Rs}$ ), Rapistrum rugosum ( $\mathrm{Rr}$ ), Sinapis arvensis (Sar), Nicotiana longiflora (N1) and Dipsacus fullonum (Df), very common in the central part of Argentina, were selected as possible source of biocides. They were used previously in traditional medicine as antimicrobial compounds (Hanlon and Barnes, 2011; Pérez Gutiérrez and Pérez, 2004; Singh and Singh, 2013; Amel et al., 2013; Al-Younis and Abdullah, 2009; Sezik et al., 2001; Martinez et al., 2004; Smith and Smith, 1942; Rosendal Jensen et al., 1979).

As is seen in Table $I$, the weed extracts tested in this research consist of a mixture of many different compounds.

Rs extracts contain substances such as amino acids, polyphenolics and alkaloids (Hanlon and Barnes, 2011; Pérez Gutiérrez and Pérez, 2004; Singh and Singh, 2013).

$\mathrm{Rr}$ possess thiofunctionalized glucosinolates, which, according to bibliographic data, have some antimicrobial activity. The bioactivity is not attributed to intact glucosinolates but, instead, to products such as isothiocyanates, organic cyanides, oxazolidinethiones and ionic thiocyanate released upon enzymatic degradation by myrosinase (thioglucoside glucohydrolase in the presence of water) (Amel et al., 2013).

The analysis of Sar extract confirmed the presence of classical antimicrobials such as phenols, tannins, flavonoids, alkaloids and saponins but glycosides, amino acids and carbohydrates, may be also found in the extracts. Phenolic extracts showed inhibitory effect on the growth of Echerichia coli and Staphylococcus aureus strains (Al-Younis and Abdullah, 2009).

Nicotine and other alkaloids are present in N1 (Martinez et al., 2004; Smith and Smith, 1942), while phenolics and alkaloids are normally found in Df extracts, together with triterpenoids and iridoids (Zhao and Shi, 2011; Rosendal Jensen et al., 1979).

\subsection{Preparation of the extracts}

The extracts from the selected weeds were obtained by refluxing the dried and crushed vegetables in methanol for 45 minutes. Afterward, the supernatant was filtered off and the solvent was eliminated under reduced pressure by rotary evaporation (Salazar et al., 2011). The extracts were conserved in the fridge at $4^{\circ} \mathrm{C}$.

\subsection{Characterization of the extracts}

Fourier transform infrared spectra (FTIR) were obtained to identify different functional groups present in the extracts. A Perkin-Elmer Spectrum One FTIR Spectrometer and the $\mathrm{KBr}$ pellet method were used.

The total soluble polyphenols (TP) content was determined by UV-Vis spectrophotometry using the Folin-Denis (FD) reagent (Ferreira et al., 2004). The amount of TP is important because these compounds are referred to as antimicrobial agents (Laks, 1987; Scalbert, 1991).

FD reagent contains sodium molybdate and tungstate salts, which, in alkaline media, reacts with phenol groups forming intense blue colored complexes. A calibration curve was done with solutions of tannic acid as reference. The absorbance of 
Table I Characteristics of the weeds used

\begin{tabular}{|c|c|c|c|c|c|c|}
\hline $\begin{array}{l}\text { Weed (Scientific } \\
\text { name) }\end{array}$ & $\begin{array}{l}\text { Argentinean } \\
\text { common name }\end{array}$ & $\begin{array}{l}\text { Common name in } \\
\text { English }\end{array}$ & Origin & $\begin{array}{l}\text { Area covered in } \\
\text { Argentina }\end{array}$ & $\begin{array}{l}\text { Main chemical } \\
\text { constituents }\end{array}$ & References \\
\hline Raphanus sativus & rábano, nabón & radish & $\begin{array}{l}\text { East Mediterranean } \\
\text { area }\end{array}$ & Whole country & $\begin{array}{l}\text { Clucosinolates, } \\
\text { acylated, } \\
\text { anthocyanins, } \\
\text { phenolics, } \\
\text { isothiocyanates, } \\
\text { methins, sapogenins, } \\
\text { amonoacids, alkaloids }\end{array}$ & $\begin{array}{l}\text { Hanlon and Barnes } \\
\text { (2011), Pérez } \\
\text { Gutiérrez and } \\
\text { Pérez (2004); Singh } \\
\text { and Singh (2013) }\end{array}$ \\
\hline $\begin{array}{l}\text { Rapistrum } \\
\text { rugosum }\end{array}$ & Mostacilla & $\begin{array}{l}\text { Annual bastard } \\
\text { cabbage }\end{array}$ & Eurasia and Africa & Whole country & $\begin{array}{l}\text { Phenols, tannins, } \\
\text { flavonoids }\end{array}$ & Amel et al. (2013) \\
\hline Sinapis arvensis & Mostaza de campo & Field mustard & Europe & Whole country & $\begin{array}{l}\text { Phenols, glycosides, } \\
\text { tannind, flavonoids, } \\
\text { carbohydrates, } \\
\text { alkaloids, aminoacids, } \\
\text { saponins }\end{array}$ & $\begin{array}{l}\text { Al-Younis and } \\
\text { Abdullah (2009) }\end{array}$ \\
\hline $\begin{array}{l}\text { Nicotiana } \\
\text { longiflora }\end{array}$ & $\begin{array}{l}\text { Tabaco de campo, } \\
\text { Sacha-tabaco }\end{array}$ & Longflower tobacco & South America & $\begin{array}{l}\text { North and Central } \\
\text { provinces }\end{array}$ & $\begin{array}{l}\text { Nicotine, alcohols, } \\
\text { terpenoids, fatty acids, } \\
\text { sterols }\end{array}$ & $\begin{array}{l}\text { Martinez et al. } \\
\text { (2004), Smith and } \\
\text { Smith. (1942) }\end{array}$ \\
\hline $\begin{array}{l}\text { Dipsacus } \\
\text { fullonum }\end{array}$ & $\begin{array}{l}\text { Cardencha, carda } \\
\text { silvestre }\end{array}$ & Wild teasel & $\begin{array}{l}\text { Eurasia and North } \\
\text { Africa }\end{array}$ & Central provinces & $\begin{array}{l}\text { Triterpenoids, iridoids, } \\
\text { phenols, alcaloids }\end{array}$ & $\begin{array}{l}\text { Rosendal Jensen } \\
\text { et al. (1979), Zhao } \\
\text { and Shi (2011) }\end{array}$ \\
\hline
\end{tabular}

the complex was measured at $750 \mathrm{~nm}$ with a UV Vis spectrophotometer (Spectrum-SP 2000 UV). The per cent of TP of each extract was calculated, with respect to the ctotal amount of extracted solids and, finally, expressed as per cent w/w.

\subsection{Antibacterial activity of the extracts}

Escherichia coli, ATCC 11229 (Gram-negative) and Staphylococcus aureus, ATCC 6538 (Gram-positive) were used to carry out the antibacterial activity tests. Strains were obtained from the collections of the University of La Plata.

The antibacterial activity was evaluated by the broth dilution method. The extracts containing the broth was serially diluted $(1: 1)$ in tubes ( 1000 to $62.5 \mathrm{ppm}$ ) that had been previously filled with $0.5 \mathrm{~mL}$ of a nutrient broth. At concentration higher than $1000 \mathrm{ppm}$, the extract solution becomes turbid and no determination could be done. The culture media was a conventional $\mathrm{R} 3$ broth $(0.1 \mathrm{~g}$ yeast extract, $0.1 \mathrm{~g}$ protease peptone, $0.1 \mathrm{~g}$ dextrose, $0.06 \mathrm{~g} \mathrm{KH}_{2} \mathrm{PO}_{4}, 0.01 \mathrm{~g} \mathrm{MgSO}_{4}$ and distilled water up to $100 \mathrm{~mL}$ ). The growth and sterility control tubes contained no extracts. After the dilutions were completed, $0.5 \mathrm{~mL}$ of the diluted microorganism suspension $\left(10^{6} \mathrm{CFU} / \mathrm{mL}\right)$ was added to all except the sterility control tube. Bacterial suspensions were obtained from R3-agar cultures incubated for $24 \mathrm{~h}$ at $37^{\circ} \mathrm{C}$. After the incubation period of $24 \mathrm{~h}$ at $37^{\circ} \mathrm{C}$, the broths were examined for assessing bacterial growth. For each extract, the lowest concentration that inhibited microorganisms' growth was referred to as the minimum inhibitory concentration (MIC).

Recounts were done in plates with R3-agar by the drop method (the Miles-Misra Method) at the highest concentration tested ( $1000 \mathrm{ppm})$. Afterwards, the most active extracts were selected to be used in paint formulation (Liao et al., 2011).

\subsection{Paint formulation and elaboration}

Paint preparation was done in a high speed disperser by mixing, in a first step, water with the different additives: dispersing, antifoaming and thickener. Then, the pigments (titanium dioxide, calcium carbonate) were added and finally the resin (an acrylic-styrene copolymer) and cosolvents were incorporated (Table II). The pigment volume concentration (volume of pigment/total volume of solids (pigment + resin), PVC) was 85.7 ; that recommended for ceiling paints (Stieg, 1973). Ceiling paints were selected because they are prone to biofilm development under normal indoor humidification cycles; principally in bathrooms and kitchens (Adam and Samson, 2011). Once the preparation was finished, the paint was filtered and kept under laboratory conditions until used.

The extracts $\mathrm{Rr}$ and $\mathrm{Nl}$ were incorporated into the original paint just before painting. These extracts were selected because they showed to be more active against the strains tested in the previous bioassay. The concentration of the biocides was 1 per cent by weight of the total paint composition. A paint without biocide was used as control.

\subsection{Assessment of the capacity of biofilm inhibition by paints}

The capacity of the experimental paints to inhibit bacterial colonization was assessed by environmental scanning electron microscopy (ESEM). S. aureus, a gram positive bacterium, was selected to do this test as it is considered one of the main causes of intrahospitals infections. Painted glasses, $0.7 \times 1.2 \mathrm{~cm}$, were immersed in $10 \mathrm{~mL}$ of culture media, with $10^{6} \mathrm{CFU} / \mathrm{mL}$ of $S$. aureus and incubated for 10 days at $37^{\circ} \mathrm{C}$. The culture media was replaced every day. After the incubation period, the samples were removed and washed three times with phosphatebuffered saline solution (PBS) to remove non-attached bacteria. Then, these panels were immersed in 2 per cent $v / v$ 
glutaraldehyde in PBS to preserve biological structures (Bellotti et al., 2014). Finally, the panels were observed by ESEM under the conditions recommended by Stobie: 6 torr, $5^{\circ} \mathrm{C}, 15 \mathrm{KV}$ (Stobie et al., 2010).

\section{Results}

\subsection{Characterization of the extracts}

The TP content of the extracts, which is generally below 4 per cent w/w, was higher in the case of Df and N1 (Figure 1).

The FTIR spectra showed that all the extract had similar organic groups, but with different concentration, as the intensity of the bands were different (Figure 2). The band between $3,600-3,050 \mathrm{~cm}^{-1}$ could be associated with $\mathrm{OH}$ groups present in aromatic or aliphatic alcohols. Df presented the most intense bands in this region. The bands which appeared at $2,980-2,920 \mathrm{~cm}^{-1}$ correspond to the stretching of C $-\mathrm{H}$ bond in nitrogenous compounds such as alkaloids (Cooper, 1980; Baranska and Schulz, 2009). Nl, Rs and Sar had shown more intense response in this region. Carbonyl stretching frequencies were localized in the region between $1,700-1,600 \mathrm{~cm}^{-1}$. The position of these bands is affected by substituents in the carbons attached to the carbonyl group; specially the presence of an aromatic ring caused the bands to appear below $1700 \mathrm{~cm}^{-1}$ (Cooper, 1980; Smith, 1999). The band around $1050 \mathrm{~cm}^{-1}$ confirmed the presence of the alcohols groups, all the extracts presented strong absorption bands at this wavelength. The band at $\sim 870 \mathrm{~cm}^{-1}$ is because of $\mathrm{C}-\mathrm{H}$ out-of-plane bending vibrations in aromatic rings; the more intense ones corresponding to $\mathrm{N} 1$ and $\mathrm{Rr}$ (Smith, 1999).

The presence of aldheydes was evidenced in the case of Df by its more intense reaction with the Tollens reactant.

\subsection{Antibacterial activity of the extracts}

The broth dilution method showed that none of the extracts completely inhibited bacterial growth at the tested concentrations. As a consequence, it was concluded that MIC was, in every case, higher than $1000 \mathrm{ppm}$. Bacterial recount was done in the tubes with the highest concentration (1000 ppm) and in the control tube. Results are shown in Figure 3, expressed as the ratio of $\log (\mathrm{CFU})_{\text {extract }} / \log (\mathrm{CFU})_{\text {control. All }}$ the extracts proved to be efficient on inhibiting the growth S. aureus $\left(\log (\mathrm{CFU})_{\text {exiracl }} / \log (\mathrm{CFU})_{\text {control }}<1\right)$, especially in the case of $\mathrm{Rr}$ and $\mathrm{Nl}$ extracts. It must be highlighted that the
Figure 1 Soluble total polyphenols for each extract using Folin-Denis regent

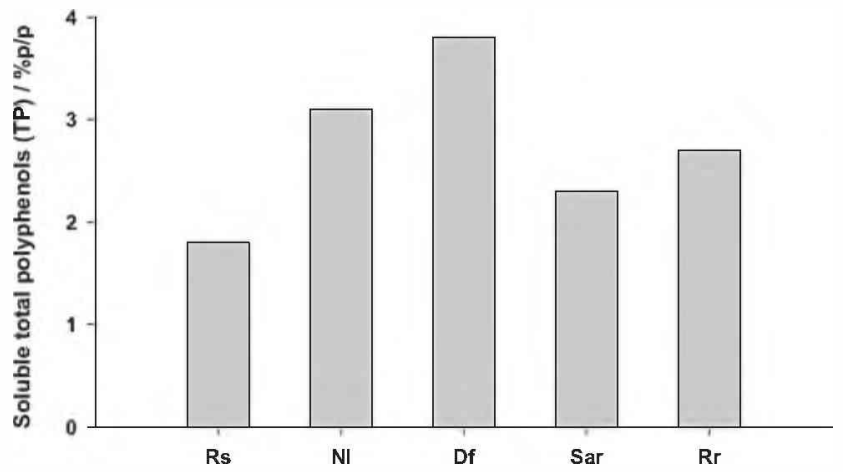

Notes: Rs: Raphanus sativus; Rr: Rapistrum rugosum; Sar: Sinapis arvensis; N1: Nicotiana longiflora; Df: Dipsacus fullonum

bacterial growth diminished two orders of magnitude in the presence of $\mathrm{Nl}$.

The antimicrobial action of the extracts toward $E$. coli inhibition was not relevant. The values of $\log (\mathrm{CFU})_{\text {extract }} / \log$

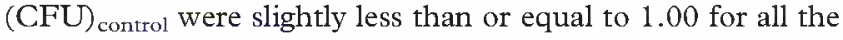
extracts (Figure 3).

\subsection{Selection of the extract to be included in paints formulation}

Taking into account the results of the previous tests, the bioactivity of $\mathrm{Rr}$ and $\mathrm{N} 1$ could be partially attributed to the presence of polyphenols as their amount, determined by FDreagent, was $\sim 3$ per cent $w / w$.

The poor antibacterial activity exhibited by Rs, Df and Sar would confirm that the only presence of polyphenols do not ensure bioactivity (Borrás-Linares et al., 2015). It must be taken into account that the antimicrobial activity could be because of the presence of a specific phenollic compound and not to all of the polyphenols present in the extract. So, a high amount of TP not always implies an important antimicrobial activity (Borrás-Linares et al., 2015).

$\mathrm{Rr}$ and $\mathrm{Nl}$ proved to be the most bioactive extracts against $S$. aureus; so, these extracts were selected to be incorporated in the formulation of antimicrobial paints.

Table II Control paint composition

\begin{tabular}{lcl}
\hline Component & $\%(w / w)$ & Brand \\
\hline Distilled water & 29.5 & - \\
Antifoaming agent & 0.26 & Thyosil Q202, Diransa \\
Celullosic thickener & 0.5 & Cellosize 52000, Dow Chemical \\
Dispersant agents & 0.39 & Poliacril D40, Diransa \\
Wetting agent & 0.13 & AMP-95, Dow Chemical \\
$\mathrm{TiO}_{2}$ & 19.0 & Zamudio \\
$\mathrm{Natural} \mathrm{CaCO}_{3}$ & 41.6 & Mica argentina \\
Precipitated CaCO & 3.7 & Mica argentina \\
Resin & 7.2 & Thyosil E 190, Diransa \\
Cosolvents & 1.9 & Butyl glycol and white spirit, Química Martin \\
\hline
\end{tabular}


Figure 2 FTIR spectra of the tested extract

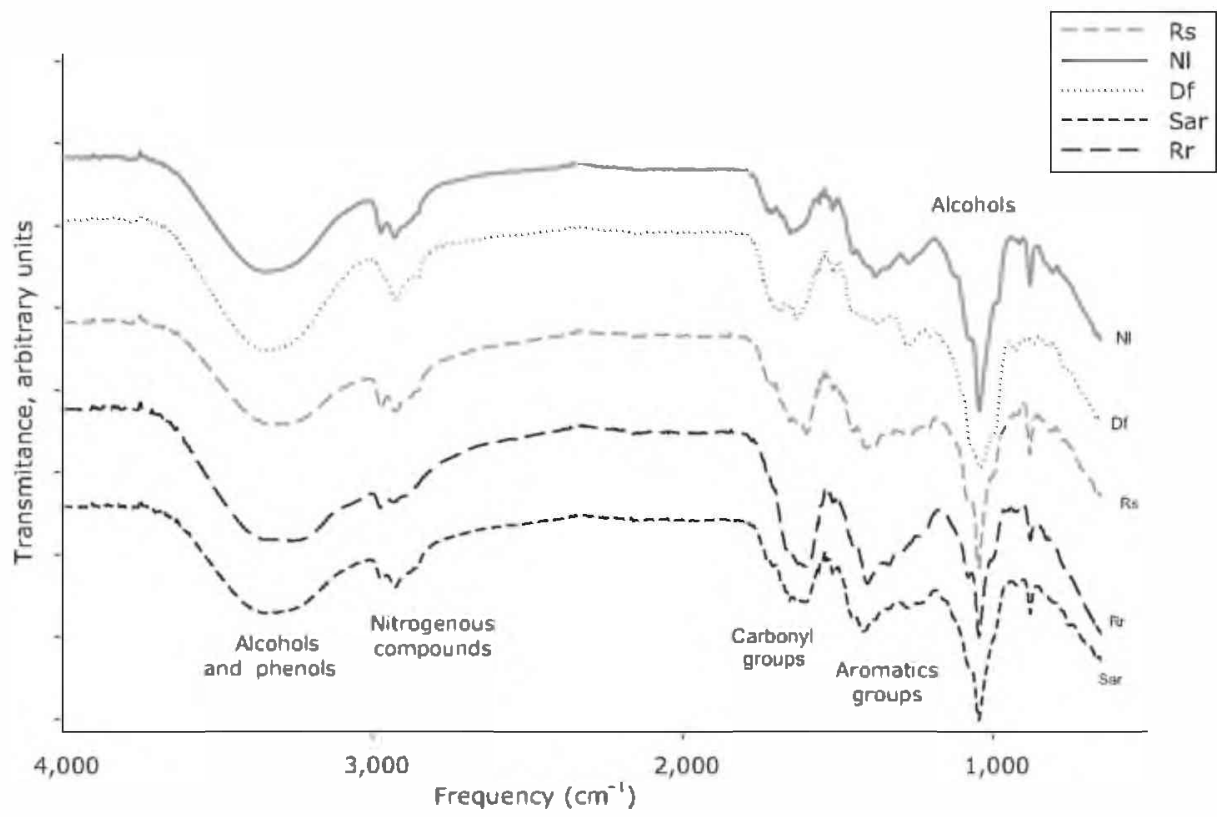

Notes: Rs: Raphanus sativus, Rr: Rapistrum rugosum, Sar: Sinapis arvensis. Nl: Nicotiana longiflora, Df: Dipsacus fullonum

Figure 3 Relative growth as logarithm (CFU/mL) extract/logarithm (CFU/mL) control, obtained from the antibacterial activity tests of $E$. coli and $\mathrm{S}$. aureus

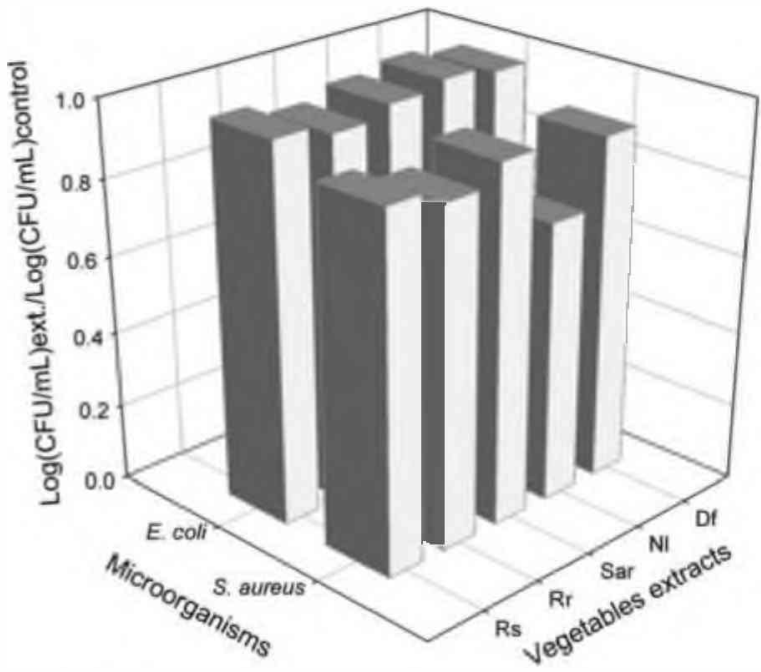

Notes: Rs: Raphamus sativus, Rr: Rapistrum rugesum, Sar: Sinanis arvensis, NI Nicollanal longitloba. DI Dipaacus fullonum

\subsection{Assessment of the capacity of biofilm inhibition by paints}

In Figure (4a) and (4b), it is clearly seen that bacteria colonized the whole surface of the control paint (without biocide). A thick biofilm with abundant extracellular material (white arrows) had completely covered the coating surface. Moreover, many bacteria emerging from the extracellular matrix could be seen; some of them were marked with black arrows (Figure $4 \mathrm{~b}$ ). These facts evidenced an active cell growth on the control coating. In general, it can be said that the tested paints were efficient in inhibiting biofilm formation, especially that formulated with $\mathrm{Nl}$ (Figure $4 \mathrm{c}$ and $\mathrm{d}$ ). In this case, micrographs revealed a coating surface without biofilm formed on it, similar to that shown by the painted panel without inoculation (Figure 4e). Only some isolated bacteria may be seen (Figure $4 \mathrm{~d}$; black arrows). These results are in accordance with those obtained in the test to determine the antibacterial activity in which Nl resulted more efficient to control $S$. aureus growth. Paint with $\mathrm{Rr}$ had lower inhibitive action; the biofilm formation was incipient but not as important as in the control paint.

\section{Conclusions}

- The selected extracts showed no significant antimicrobial action against $E$. coli, but, in change, they appeared to be selective on controlling the growth of $S$. Aureus.

- The antimicrobial action seemed not to be related to the total polyphenols content. Other compounds present in the extracts could be responsible of their antimicrobial action.

- MIC was, in every case, higher than 1,000 ppm. Bacterial growth diminished, at least, two orders of magnitude in the case of Nicotiana longiflora.

- The acrylic-styrene waterborne paint containing $N$. longiflora extract was the most effective one on inhibiting S. aureus biofilm formation. The inhibition of biofilm growth became perceivable even at concentrations of $\sim 1$ per cent of the extract. 
Figure 4 Micrographs (15 kV) obtained by ESEM of: (a) and (b) control paints (without biocides), the black and white arrows show extracellular matrixembedded bacteria and abundant extracellular material respectively; (c) and (d) paint with Nicotiana Longiflora extract, the black arrows show some isolated bacteria; (e) control paint not inoculated

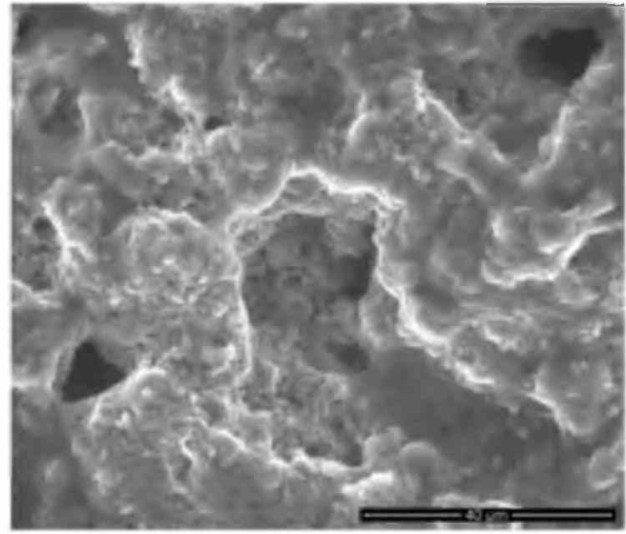

(a)

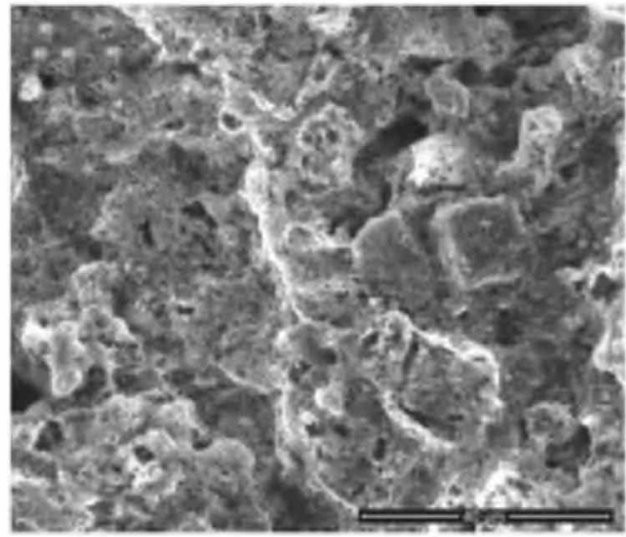

(c)

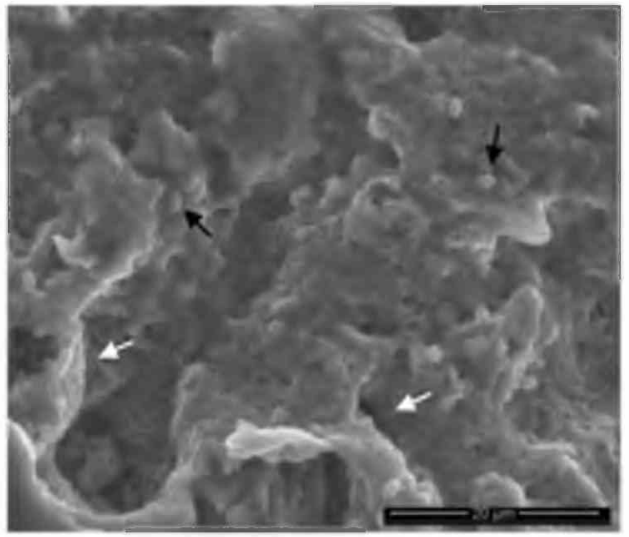

(b)

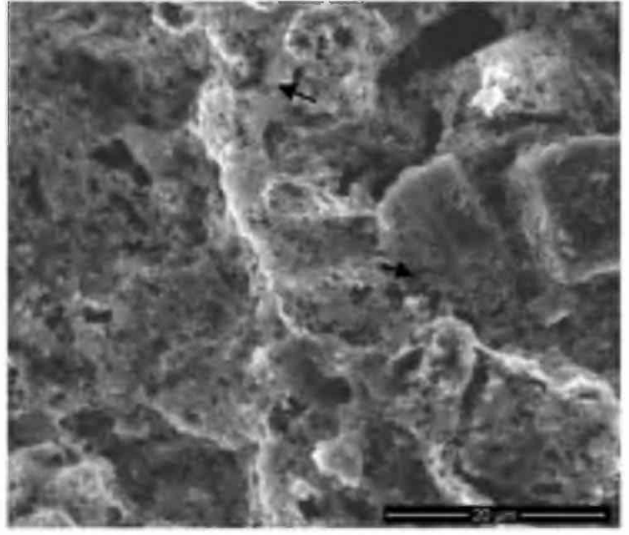

(d)

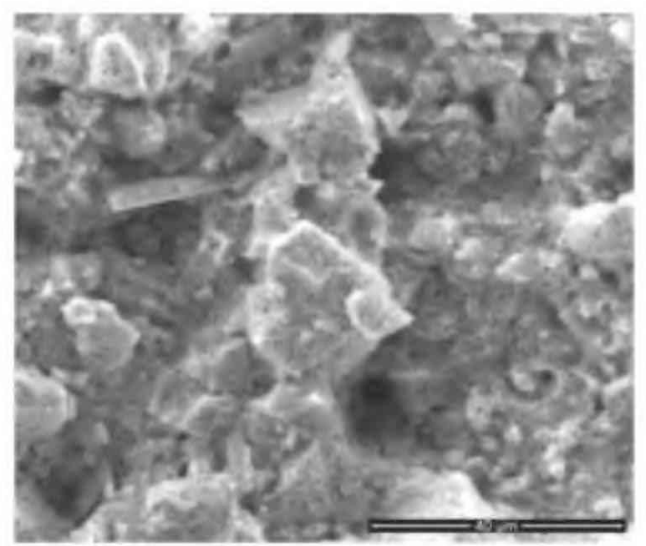

(e)

\section{References}

Adam, O.C.G. and Samson, R.A. (2011), Fundamentals of Mold Growth in Indoor Environments and Strategies for Healthv Living. Wageningen Academic Publishers.

Al-Younis, N. and Abdullah, A.F. (2009), "Isolation and antibacterial evaluation of plant extracts from some medicinal plans in Kurdisan region", Foumal of Duhok University, Vol. 12 No. 1, pp. 250-255.

Amel, H., Malek, B.H., Hichem, B.J., Ali, L., Mahjoub, A. and Boulbaba, S. (2013), "Antioxidant and antiacetulcholinesterase acrtivities of extracts from Rapistrum Rugosum in Tunisia", Asian Pacific Foumal of Trobical Disease, Vol. 3 No. 5, pp. 367-374. 
Baranska, M. and Schulz, H. (2009), "Determination of alkaloids through infrared and raman spectroscopy", in Cordell. G.A. (Ed.), The Alkaloids, Elsevier.

Bellotti, N., Del Amo, B. and Romagnoli, R. (2014), "Assessment of tannin antifouling coatings by scanning electron microscopy", Progress in Organic Coatings, Vol. 77 No. 9, pp. 1400-1407.

Binorkar, S.V. and Jani, D.K. (2012), "Traditional medicinal usage of tobacco - a review", Spatula DD - Peer Reviewed Foumal on Complementarv Medicine and Drug Discoverv, Vol. 2 No. 2, pp. 127-134.

Bonjar, S. (2004), "Evaluation of antibacterial properties of some medicinal plants used in Iran", foumal of Ethnopharmacology, Vol. 94 Nos 2/3, pp. 301-305.

Borrás-Linares, I., Fernández-Arroyo, S., Arráez-Roman, D., Palmeros-Suárez, P.A., Del Val-Díaz, R., AndradeGonzáles, I., Fernández-Gutiérrez, A., Gómez-Leyva, J.F. and Segura-Carretero, A. (2015), "Characterization of phenolic compounds, anthocyanidin, antioxidant and antimicrobial activity of 25 varieties of Mexican Roselle (Hibiscus Sabdariffa)", Industrial Crops and Products, Vol. 69, pp. 385-394.

Cooper, J.W. (1980), Spectropic Techniques for Organic Chemists, Wiley-Interscience Publication.

Costerton, J.W., Stewart, P.S. and Greenberg, E.P. (1999), "Bacterial biofilms: a common cause of persistent infections", Science, Vol. 284 No. 5418, pp. 1318-1322.

Costerton, J.W., Lewandowski, Z., Cadwell, D.E., Korve, R. D.L. and Lappin-Scott, H.L. (1995), "Microbial biofilms", Anmual Review of Microbiologv. Vol. 49, pp. 711-745.

Ferreira, E.C., Nogueira, A.R.A., Souza, G.B. and Batista, L. A.R. (2004), "Effect of drying method and length of storage on tannin and total phenol concentrations in pigeon pea seeds", Food Chemistry, Vol. 86(1), pp. 17-23.

Garg, K.L., Jain, K.K. and Mishra, A.K. (1995), "Role of fungi in the deterioration of wall paintings", The Science of the Total Environment, Vol. 167 Nos1/3, pp. 255-271.

Gilbert, P., Allison, D.G. and Mcbain, A.J. (2002), "Biofilms in vitro and in vivo: do singular mechanisms imply crossresistance?", foumal of Anolied Microbiology, Vol. 92 No. s1, pp. $98 \mathrm{~S}-110 \mathrm{~S}$.

Guerrero, G., Amalric, J., Mutin, P.-H., Sotto, A. and Lavigne, J.-P. (2009), "Inhibition of bacterial adhesion and prevention of biofilm formation: use of organic selfassembled monolayers on inorganic surfaces", Pathalogie Biologie, Vol. 57 No. 1, pp. 36-43.

Hanlon, P.R. and Barnes, D.M. (2011), "Phytochemical composition and biological activity of 8 varieties of radish (Raphanus sativus L.) sprouts and mature taproots", Zournal of Food Science, Vol. 76 No. 1, pp. C:185-C:192.

Hare, C. (2000), "Microbiologicalinfluenced attack of coatings", Foumal of Protective Coatings and Linings, pp. 51-65.

Héquet, A., Humblot, V., Berjeaud, J.-M. and Pradier, C.-M. (2011), "Optimized grafting of antimicrobial peptides on stainless steel surface and biofilm resistance tests", Colloids and Surfaces B: Biointerfaces, Vol. 84 No. 2, pp. 301-309.

Hoque, J., Akkapedd, P., Yadav, V., Manjunath, G.B., Uppu, D.S., Konai, M.M., Yarlagadda, V., Sanyal, K. and Haldar, J. (2015), "Broad spectrum antibacterial and antifungal polymeric paint materials: synthesis, structure-activity relationship, and memly-brane-active mode of action", ACS Anoliad Materials and Interfaces, Vol. 7, pp. 1804-1815.

Inoue, Y., Shiraishi, A., Hada, T., Hirose, K., Hamashima, H. and Shimada, J. (2004), "The antibacterial effects of terpene alcohols on Staphylococcus aureus and their mode of action", FEMS Microbiology Letters, Vol. 237 No. 2, pp. 325-331.

Johns, K. (2003), "Hygienic coatings: the next generation", Surface Coatings International, Vol. 86 No. 2, pp. 101-110.

Kramer, A., Schwebke, I. and Kampf, G. (2006), "How long do nosocomial pathogens persist on inanimate surfaces? a systematic review", BMC Infectious Diseases, Vol. 6, pp. 130-138.

Laks, P.E. (1987), "Flavonoid biocides: Phytoalexin analogues from condensed tannins", Phvtochemistrv. Vol. 26 No. 6, pp. 1617-1621.

Liao, S.G., Zhang, L.J., Sun, F., Zhang, J.J., Chen, A.Y., Lan, Y.Y., Li, Y.J., Wang, A.M., He, X., Xiong, Y., Dong, L., Chen, X.J., Li, Y.T., Zuo, L. and Wang, Y.L. (2011), "Antibacterial and anti-inflammatory effects of extracts and fractions from Polygonum capitatum", foumal of Ethnopharmacologv, Vol. 134 No. 3, pp. 1006-1009.

Martinez, M.R., Pochettino, M.L. and Cortella, A.R. (2004), "Environment and illness in the Calchaqui Valley (Salta, Argentina): phytotherapy for osteo-articular and cardiocirculatory diseases", f Fithnohanmacel, Vol. 95, pp. 317-327.

Otto, M. (2013), "Staphylococcal infections: mechanims of biofilm maturation and detachment as critical determinants of pathogenicity ", Ammual Review of Medicine, Vol. 64 No. 1, pp. 175-188.

Pérez Gutiérrez, R.M. and Pérez, R.L. (2004), "Raphanus sativus (radish): their chemistry and biology", The Scientific World Yournal, Vol. 4, pp. 811-837.

Rosendal Jensen, W., Lyse-Petersen, S.E. and Nielsen, J. (1979), "Novel bis-iridoid glucosides form Dispacus Sylvestris", Phvtochemistru, Vol. 18 No. 2, pp. 273-277.

Salazar, M.O., Micheloni, O., Escalante, A.M. and Furlan, R. L.E. (2011), "Discovery of b-glucosidase inhibitor from a chemically engineered extract through sulfonylation", Molecular Diversity, Vol. 15 No. 3, pp. 713-719.

Sambhy, V., Macbride, M.M., Peterson, B.R. and Sen, A. (2006), "Silver Bromide nanoparticle/polymer composites: dual action tunable antimicrobial materials", foumal of the American Chemical Societv, Vol. 128 No. 30, pp. 9798-9808.

Scalbert, A. (1991), "Antimicrobial properties of Tannins", Phvtochemistrv, Vol. 30 No. 12, pp. 3875-3883.

Schneider, P.M. (2013), "New technologies and trends in sterilization and disinfection", American Foumal of Infection Control, Vol. 41 No. S5, pp. S81-S86.

Sezik, E., Yeşilada, E., Honda, G., Takaishi, Y., Takeda, Y. and Tanaka, T. (2001), "Traditional medicine in Turkey X. Folk medicine in Central Anatolia", foumal of Ethnopharmacologv, Vol. 75 No. 2-3, pp. 95-115.

Singh, P. and Singh, J. (2013), "Medicinal and therapeutic utilities of Raphans sativus K”, Int. F. Plant, Animal and Environm. Sci, Vol. 3, pp. 103-105.

Smith, B. (1999), Infrared Spectral Interpretation, CRC Press.

Smith, H.H. and Smith, C.R. (1942), "Alkaloids in certain species and interspecific hybrids of nicotiana”, f. Agric. Research, Vol. 65, pp. 347-359. 
Sontakke, T.K., Jagtap, R.N., Singh, A. and Kothari, D.C. (2012), "Nano ZnO grafted on MAA/BA/MMA copolymer: an additive for hygienic coating", Progress in Orgamic Coatings, Vol. 74 No. 3, pp. 582-588.

Stieg, F.B. (1973), "The influence of PVC on paint properties", Pmoress in Oramic Coating, Vol. 1 No. 4, pp. 351-373.

Stobie, N., Duffy, B., Colreavy, J., Mchale, P., Hinder, S.J. and Mccormack, D.E. (2010), "Dual-action hygienic coatings: benefits of hydrophobicity and silver ion release for protection of environmental and clinical surfaces", Fournal of Colloid and Interface Science, Vol. 345 No. 2, pp. 286-292.

Tenke, P., Riedl, C.R., Jones, G.L., Williams, G.J., Stickler, D. and Nagy, E. (2004), "Bacterial biofilm formation on urologic devices and Herapin coating as a preventive strategy", Intemational foumal of Antimicrobial Agents, Vol. 23, pp. S67-S74.
Videla, H.A. and Herrera, L.K. (2005), "Microbiologically influenced corrosion: looking to the future", Intemational Microbiologu, Vol. 8, pp. 169-180.

Weber, D.J., Anderson, D. and Rutala, W.A. (2013), "The role of the surface environment in healthcare-associated infections", Current Obinion in Infectious Diseases. Vol. 26 No. 4, pp. 338-344.

Yebra, D.M., Kiil, S., Weinell, C.E. and Dam-Johansen, K. (2006), "Effects of marine microbial biofilm on the biocide release rate from antifouling paints- a model-based analysis", Progress in Organic Coating. Vol. 57 No. 1, pp. 56-66.

Zhao, Y.-M. and Shi, Y.-P. (2011), "Phytochemicals and biological activities of Dipsacus species", Chemistry Eamp: biodiversitv, Vol. 8 No. 3, pp. 414-430.

\section{Corresponding author}

Cecilia Deya can be contacted at: c.deya@cidepint.gov.ar 